\title{
Priestorové rozloženie volebnej účasti v parlamentných vol'bách v slovenských okresoch v rokoch 1990 až 2016
}

\author{
Dominik KEVICKÝ
}

\begin{abstract}
Spatial distribution of voter turnout of the parliamentary elections in Slovak districts in $1990-2016$

Abstract: This study gives a basic overview of the distribution of electoral turnout in Slovak parliamentary elections in the period 1990 - 2016. The aim is to assess the stability of voter turnout and identify its spatial patterns. The pattern of stability of the spatial distribution is examined by the modified method of identification of electoral support areas developed by Jehlička and Sýkora (1991). The results of the analysis show, that the voter turnout in the 1990 s was characterized by significant instability compared to electoral participation after the year 2000. The long-term low participation is mainly in the districts of eastern and southern Slovakia and also in the Záhorie region. Until 2000, Bratislava had a low voter turnout, but since the elections in 2002, the turnout has increased. The long-term high electoral participation can be observed mainly in the regions of Žilina and Trenčin. The district with the highest voter turnout throughout the mentioned period is Tvrdošin. This study highlights several interesting aspects of the distribution of electoral turnout, which could be explored by further studies.
\end{abstract}

Keywords: Electoral Geography, Parliamentary Elections, Voter Turnout, Slovakia

\section{Úvod}

Na Slovensku sa od roku 1989 konalo devät’ volieb do parlamentu a v rámci viac ako dvadsat'pät'ročnej histórie demokratického zriadenia sa vyvíjala i volebná účast' na Slovensku. Najvyššia účast' bola dosiahnutá v prvých vol'bách do Slovenskej národnej rady, konaných v roku 1990. Celoslovenská volebná účast' v týchto vol'bách bola viac ako $95 \%$ a vo všetkých okresoch Slovenska sa volebná účast' pohybovala nad $90 \%$. Avšak, už v nasledujúcich vol'bách v roku 1992 poklesla volebná účast' o 10 percentuálnych bodov a volebná účast' nad’alej klesala, s výnimkou volieb v roku 1998, ktoré boli v rámci Slovenska špecifické (Krivý 1999), až dosiahla vo vol'bách v roku 2006 svoje historické minimum (54,7\%). Dokonca v niektorých okresoch sa volieb nezúčastnila ani polovica oprávnených voličov. V posledných troch vol'bách v rokoch 2010, 2012 a 2016 sa volebná účast' ustálila na hodnote mierne pod $60 \%$.

Volebná účast' môže výrazne ovplyvnit’ výsledky volieb a tým pádom patrí analýza priestorovej diferenciácie volebnej účasti k dôležitým témam, ktorým by sa volebná geografia mala venovat'. Napriek tomu podl'a Plešivčáka et al. (2016) na Slovensku nebol uskutočnený dlhodobý a systematický výskum volebnej účasti. Väčšina autorov sa venuje problematike volebnej účasti len ako súčast' celkovej analýzy volieb na Slovensku. Český geograf Kostelecký (2001) sa snažil určit', v ktorých okresoch bola v rokoch 1992 až 1998 vysoká volebná neúčast' a pomocou regresnej analýzy hl'adal faktory, ktoré volebnú neúčast' ovplyvnili. Zistil, že volebná účast' bola nízka v okresoch s vysokou mierou kriminality a vysokou priemernou mzdou zamestnancov - čiže v metropolitných oblastiach Bratislavy a Košíc. Krivý (2012) v rámci analýzy výsledkov volieb do parlamentu v roku 2012 skúmal i volebnú účast' a okrem iného si všimol, že dochádza k poklesu volebnej účasti v obciach s vysokým zastúpením mad’arského

DOI: https://doi.org/10.33542/GC2020-1-04 
obyvatel'stva. Madleňák (2012) skúmal regionálne rozdiely volebnej účasti v štyroch parlamentných vol'bách od roku 1998 do roku 2010. Pritom slovenské okresy rozdelil do piatich kategórií podl'a toho, aká vel'ká bola odchýlka volebnej účasti v okrese od priemernej volebnej účasti. Madleňák a Pink (2012) analyzovali územia so stabilne vysokou volebnou účast'ou a so stabilne vysokou volebnou neúčast'ou v rokoch 1994 až 2010. Podobnú analýzu robili i Gyárfášová a Krivý (2013), avšak tí analyzovali parlamentné vol’by v rokoch 1990 až 2012. Mikuš (2014) skúmal okresy s nadpriemernou, respektíve podpriemernou volebnou účast’ou a tiež si všímal, v kol'kých vol'bách mali okresy nadpriemernú, respektíve podpriemernú účast'. Povšimol si, že priestorové rozloženie volebnej účasti v okresoch sa vel'mi podobá rozloženiu miery evidovanej nezamestnanosti. Všetky spomenuté štúdie zaznamenali, že vysoká volebná účast' je v oblastiach západného a stredného Slovenska a naopak nízka volebná účast' je výraznejšie zastúpená v regiónoch na východe Slovenska. Pravdepodobne jedinou slovenskou prácou zameranou čisto na volebnú účast’ je článok Mikuša a Gurňáka (2014). Ten sa venuje špecifikám volebnej účasti v obciach Košického kraja v rokoch 1999 až 2014. Kostelecký a Krivý (2015) skúmali urbánno-rurálne rozdiely volebnej účasti na Slovensku. Analyzovali rozdiely priemernej výšky volebnej účasti vo vel'kostných kategóriách obcí a povšimli si, že vysoká volebná účast' je $\mathrm{v}$ najmenších obciach a postupom času narastala i v najväčších mestách.

Ciel'om tohto príspevku je zistit', ako je volebná účast' v parlamentných vol'bách priestorovo diferencovaná a hlavne, či sa dá hovorit' o stabilite priestorového rozloženia volebnej účasti na Slovensku v skúmanom období, alebo dochádza k výraznej premene jej rozloženia. Štúdia tiež identifikuje okresy, ktoré si po celé obdobie udržujú stabilnú výšku volebnej účasti a okresy, u ktorých dochádza k výraznej zmene výšky volebnej účasti.

\section{Teoretické prístupy k stabilite volebnej účasti}

Už prvé vedecké štúdie analyzujúce správanie sa voličov poukázali na to, že l'udia majú tendenciu sa stabilne zúčastňovat', respektíve nezúčastňovat' volieb (Campbell et al. 1960). Táto stabilita občanov zúčastňovania sa volieb viedla niektorých autorov (Green, Shachar 2000, Franklin 2004) k tomu, že prišli s teóriou habituálneho hlasovania. Teória habituálneho hlasovania vychádza z toho, že ten, kto sa zúčastnil volieb v minulosti, má väčšiu pravdepodobnost', že sa zúčastní volieb i v budúcnosti. Väčšiu pozornost' tejto problematike akcentovali vo svojom článku Green a Shachar (2000). Uvedení autori vo svojom výskume zistili, že hlasovanie vo vol'bách obsahuje pre občana určitý prvok zvyku. Je to preto, že u občana sa postupom času vytvára zvyk byt' alebo nebyt' súčast'ou volebného procesu, podl'a toho, či sa zúčastňuje alebo nezúčastňuje volieb. A čím dlhšie sa podiel'a alebo nepodiel'a na volebnej účasti, tým sa vytvára silnejší zvyk. Preto pre autorov tejto teórie je dôležitá znalost' volebnej účasti vo vol'bách predchádzajúcich (Franklin 2004). Podl'a tejto teórie by sa malo očakávat', že volebná účast' by mala byt' stabilná.

Iné teórie však počítajú zo zmenou volebnej účasti v čase. Teória modernizácie predpokladá, že rastúce hodnoty socioekonomických charakteristík naznačujú zvyšujúcu sa modernizáciu spoločnosti, ktorá vytvára vyššie nároky na aktívnejšiu účast' obyvatel'ov na rozhodovacích procesoch (Norris 2002). V dôsledku toho majú rozvinutejšie regióny vyššiu volebnú účast'. Podl'a tejto teórie býva vyššia volebná účast' hlavne v mestskom prostredí, pretože obyvatelia v mestách bývajú zvyčajne viac vzdelanejší, majú väčšie finančné príjmy a pre politické strany je efektívnejšie viest' mobilizačné kampane vo väčších mestách, pretože tým ovplyvnia väčší počet potenciálnych voličov (Mo, Brady, Ro 1991).

Na druhej strane si viacerí autori analyzujúci volebnú účast’ v postsocialistických krajinách všimli nízku účast' práve v mestskom prostredí (Kostadinova 2003, Pacek, Pop-Eleches, Tucker 2009). Nový (2013) podotýka, že špecifiká socialistického rozvoja spôsobili po páde so- 
cializmu v štátoch ekonomické a politické problémy. Preto aj ked' sociálne a ekonomické ukazovatele na agregovanej úrovni rastú, kvalita života niektorých občanov mohla poklesnút' a oni sa rozhodli stiahnut' z politického života. Z týchto predpokladov vychádza teória rozčarovania, ktorá vysvetl'uje, prečo s rastúcim stupňom socioekonomického pokroku volebná účast' v postsocialistických štátoch klesá namiesto toho, aby podl’a teórie modernizácie rástla, a prečo najväčšie mestá majú nízku volebnú účast'.

Teória socioekonomického statusu a zdrojov zahŕňa niekol'ko prístupov, ktoré vysvetl'ujú volebnú účast' na základe ekonomických a sociálnych charakteristík jednotlivých občanov. K vysvetleniu volebnej účasti bývajú použité ukazovatele ako je vzdelanie, príjem, typ zamestnania, nezamestnanost', pohlavie či vek osoby a ciel'om teórie je určit', aké socioekonomické charakteristiky jednotlivcov ovplyvňujú účast'. Podl’a tejto teórie sa volieb viac zúčastňujú jedinci s vyšším socioekonomickým statusom, pretože majú viac zdrojov (peniaze, schopnosti, čas...), vd’aka ktorým sa im znížia náklady na hlasovanie a získajú zisky z hlasovania (Wolfinger, Rosenstone 1980). V rámci stability by sa tak volebná účast' nemala menit’ v okresoch, v ktorých nedochádza k zmenám socioekonomických charakteristík. Táto štúdia sa zameriava konkrétne na mieru nezamestnanosti, pretože táto socioekonomická premenná sa v čase vyvíja najdynamickejšie.

Teória mobilizácie vychádza z toho, že rozhodnutie íst' volit’ nevychádza len z osobných hodnôt a postojov občanov, ale že ich výrazne ovplyvňuje aj ich okolie a voliči sú politický mobilizovaní. Rosenstone a Hansen $(2009$, p. 25) označujú za politickú mobilizáciu proces, pri ktorom kandidáti, politické strany, aktivisti a ostatné záujmové skupiny presviedčajú občanov k politickej participácii. Autori rozlišujú dva typy mobilizácie, a to priamu a nepriamu. Za priamu mobilizáciu považujú také prípady, ked' je potenciálny volič oslovený politickou stranou alebo kandidátmi. K metódam tejto mobilizácie sa radia predvolebné mítingy, kontaktovanie voličov telefónom, poštou alebo elektronicky. V prípade nepriamej mobilizácie je človek oslovený l'ud'mi zo svojho okolia, aby sa zúčastnil volieb. Môže byt' mobilizovaný svojimi priatel'mi, kolegami z práce, susedmi, členmi spolku alebo náboženskej komunity, ku ktorým patrí. Dôležitú úlohu môže zohrávat' aj príslušnost' k určitej národnostnej menšine. Ak má daná menšina svoje politické zastúpenie, môže to zvyšovat' jej mobilizáciu zúčastňovat' sa volieb (Krivý 2012, Szabó, Tátrai 2016).

Z predchádzajúcich teórií sa dá predpokladat' niekol'ko výsledkov. Ak by sa potvrdila teória habituálneho hlasovania, tak by sa stabilita volebnej účasti medzi regiónmi nemala výrazne menit'. Podl'a teórie modernizácie, by mala časom narastat' v najvyspelejších regiónoch Slovenska, ktoré sú hlavne na západe štátu a naopak, podl’a teórie rozčarovania, by mala byt' volebná účast' nízka v najväčších a najvyspelejších mestách. V prípade, že volebná účast' by bola stabilne nízka v okresoch, v ktorých je dlhodobo vysoká nezamestnanost', tak to bude hovorit' v prospech teórie socioekonomického statusu a zdrojov.

\section{Metodika}

Vo volebnej geografii existuje niekol'ko metód, ktoré slúžia na určovanie priestorovej diferenciácie a stability volebnej účasti v regiónoch. Napríklad je možné rozdel'ovat' regióny do jednotlivých kategórií pomocou zvolených intervalov výšky volebnej účasti. Ako vstupné dáta na určenie intervalov sa používajú absolútne hodnoty volebnej účasti, relatívne hodnoty volebnej účasti alebo ich kombinácia na úrovni celého štátu, ale i regiónu. V tejto štúdii bola použitá kombinácia absolútnych a relatívnych hodnôt volebnej účasti v regiónoch.

$\mathrm{Na}$ určenie území s vysokou, respektíve nízkou volebnou účastou, bola použitá metóda Jehličku a Sýkoru (1991). Táto metóda sa tradične používa na určenie územia volebnej podpory politických strán a bola použitá už v mnohých štúdiách skúmajúcich volebné prostredie Slovenskej republiky (napr. Baráth et al. 1995, Szőllős 2000, Plešivčák 2011). Avšak niektorí 
autori použili túto metódu aj k hodnoteniu diferenciácie volebnej účasti v okresoch (Madleňák a Pink 2012).

Pre každé vol'by sme okresy zoradili zostupne podl’a relatívnej hodnoty volebnej účasti. Následne sme pre každý okres vypočítali percentuálny podiel počtu zúčastnených voličov v okrese zo všetkých zúčastnených voličov na Slovensku. Po výpočte percentuálneho podielu počtu zúčastnených voličov sme urobili kumulovaný súčet týchto hodnôt a podl'a neho rozdelili okresy do štyroch kategórií. Okresy, v ktorých sa nachádzala prvá štvrtina všetkých zúčastnených voličov boli označené ako „okres s výrazne vysokou volebnou účast'ou“. Okresy v druhej štvrtine boli označené ako „okres s vysokou volebnou účast'ou“, okresy v tretej štvrtine boli označené ako „okres s nízkou volebnou účast’ou“ a okresy v poslednej štvrtine boli označené ako „okres s výrazne nízkou volebnou účast'ou“. V prípade okresov, ktoré sa nachádzali na hranici dvoch kategórií, boli tieto okresy priradené do tej kategórie, v ktorej mali väčšie zastúpenie (napr. ak bol okres ohraničený hodnotami $24,5 \%$ a 25,2 \%, tak bol zaradený do kategórie okres s výrazne vysokou volebnou účast'ou).

Za okres so stabilnou volebnou účast'ou sa považoval ten, ktorý bol v skúmanom rozmedzí vždy označený ako okres s výrazne vysokou volebnou účast'ou alebo ak v skúmanom období bol daný okres v jednotlivých vol'bách označený za okres s výrazne vysokou volebnou účast'ou a okres s vysokou volebnou účast'ou. V prvom prípade sa potom tento okres označoval ako okres so stabilne výrazne vysokou volebnou účast'ou a v druhom prípade ako okres so stabilne vysokou volebnou účast'ou. Rovnakým postupom sa určovala stabilita i u okresov s nízkou volebnou účast'ou.

Stabilita volebnej účasti v parlamentných vol'bách sa skúmala na vol'bách uskutočnených v období rokov 1990 až 2016 na úrovni okresov. V tomto období sa konali dve vol’by do Slovenskej národnej rady (1990 a 1992) a sedem volieb do Národnej rady Slovenskej republiky. Údaje o volebnej účasti z volieb v rokoch 1990, 1992 a 1994 boli prepočítané na súčasné okresy, ktoré sú v platnosti od roku 1996. Bratislavské a košické mestské okresy boli z funkčného hl'adiska zlúčené do jedného celku. Tak sa v štúdii pracovalo so 72 územnými jednotkami.

Dáta o volebnej účasti za jednotlivé okresy boli prevzaté z databázy Vladimíra Krivého (2016), ktorá obsahuje výsledky parlamentných volieb na Slovensku na úrovni obcí od roku 1929 až po vol'by v roku 2016. Údaje o miere evidovanej nezamestnanosti boli získané z internetového portálu Ústredia práce, sociálnych vecí a rodiny (2018). Za dlhodobú nezamestnanost' v tejto štúdii označujeme podiel l'udí, ktorí sú bez zamestnania viac ako 12 mesiacov k ekonomicky aktívnemu obyvatel'stvu.

\section{Výsledky}

Za celé skúmané obdobie malo stabilnú účast' celkovo 13 okresov na Slovensku (vid' obr. 1). Okresy so stabilne vysokou volebnou účast'ou sú prevažne zoskupené na severe stredného Slovenska. Patria tam okresy Tvrdošín, Liptovský Mikuláš, Turčianske Teplice, Kysucké Nové Mesto, Trenčín, Púchov a Zlaté Moravce, pričom okres Tvrdošín je jediným okresom, ktorý sa v období 1990 až 2016 vyznačoval stabilne výraznou vysokou volebnou účast'ou. Naproti tomu sa šest' okresov so stabilne nízkou volebnou účast'ou nachádza na východnom a južnom Slovensku. Ide o mesto Košice, d'alej o okresy Lučenec, Revúca, Snina, Michalovce a Trebišov. Posledné dva okresy boli okresy so stabilne výrazne nízkou volebnou účast'ou.

Ak z analýzy vynecháme prvé vol'by z roku 1990, ktoré sa vyznačovali vysokou volebnou účast'ou a boli svojím spôsobom špecifické, tak pribudlo viacero okresov so stabilnou účast'ou (vid' obr. 2). Nové okresy so stabilne vysokou volebnou účast'ou sú okresy Zvolen a Topol'čany. Ku okresom so stabilne nízkou volebnou účast'ou pribudli okresy Kežmarok, Šal’a a dva okresy na Záhorí (okresy Skalica a Malacky). 


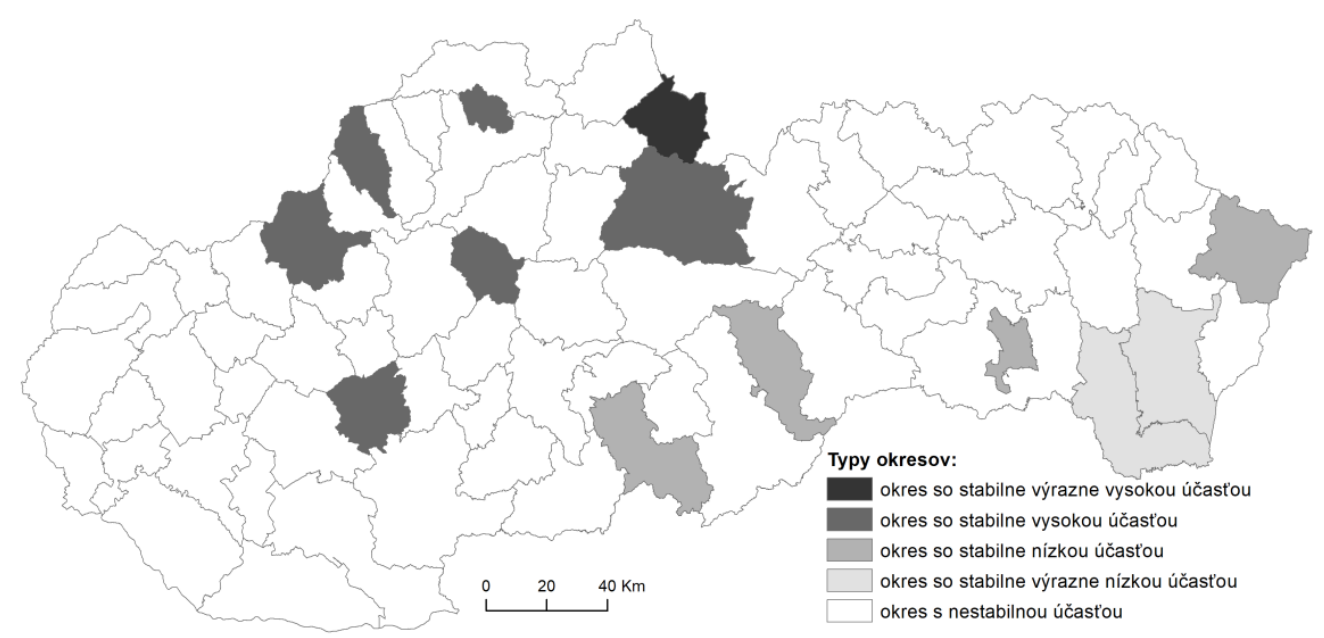

Obr. 1. Okresy so stabilnou volebnou účast'ou vo vol'bách v rokoch 1990 až 2016; Zdroj: Krivý (2016), vlastné výpočty

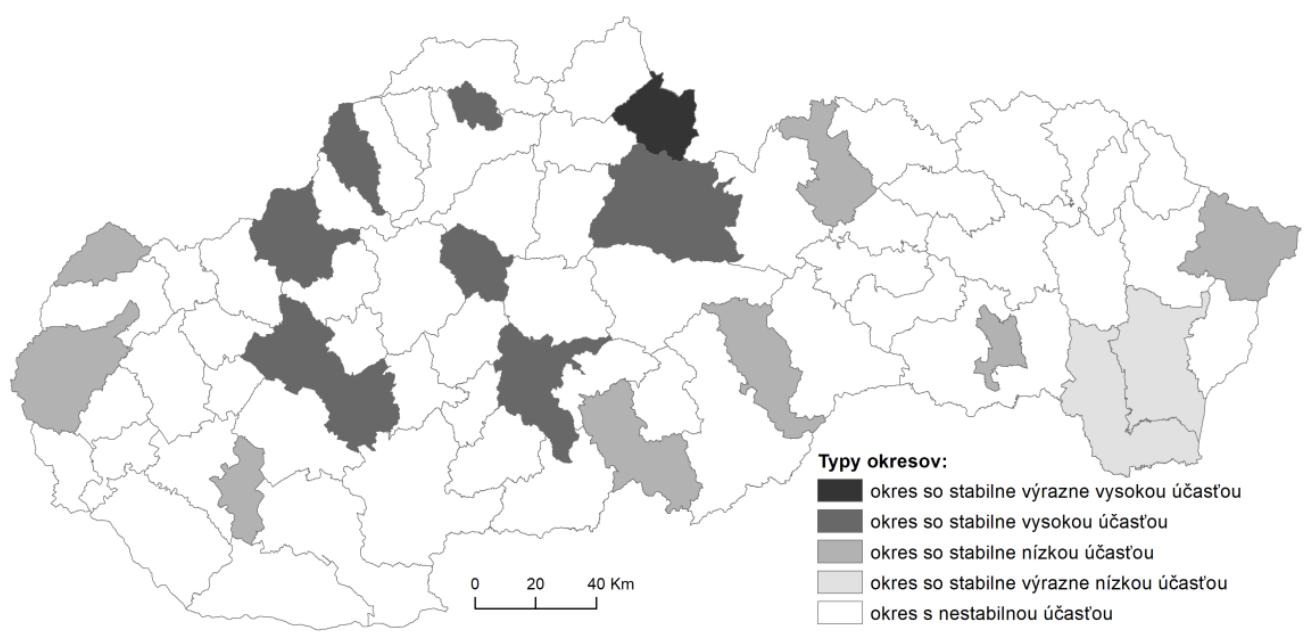

Obr. 2. Okresy so stabilnou volebnou účast'ou vo vol'bách v rokoch 1992 až 2016; Zdroj: Krivý (2016), vlastné výpočty

Teraz sa pozrieme na rozdiel rozloženia stability volebnej účasti vo vol'bách uskutočnených v 90. rokoch 20. storočia a vo vol'bách uskutočnených po roku 2000. Stabilitu volebnej účasti v devät'desiatych rokoch ukazuje obrázok 3 . V štyroch vol'bách, ktoré sa konali v tomto období, bolo celkom 26 okresov na Slovensku so stabilnou volebnou účast'ou. Stabilne výrazne nízka volebná účast’ bola v Bratislave a na Zemplíne (okresy Michalovce, Snina a Trebišov) a nízka volebná účast' bola tiež v okresoch Revúca, Lučenec, Čadca a v meste Košice. Naproti tomu okresy so stabilne vysokou volebnou účast’ou sa zhlukujú do troch celkov. Prvý tvorí pás okresov od Trenčína, cez Zlaté Moravce, Žiar nad Hronom až po Turčianske Teplice. Druhý zhluk sa nachádza na severe Slovenska a tvoria ho okresy Ružomberok, Liptovský Mikuláš, Dolný Kubín a Tvrdošín. Tretí väčší celok okresov so stabilne vysokou účastou je na východnom Slovensku (okresy Gelnica, Prešov a Sabinov). Okrem týchto troch zhlukov mali stabilne vysokú volebnú účast' okresy Poltár, Krupina, Púchov a Kysucké Nové Mesto. 


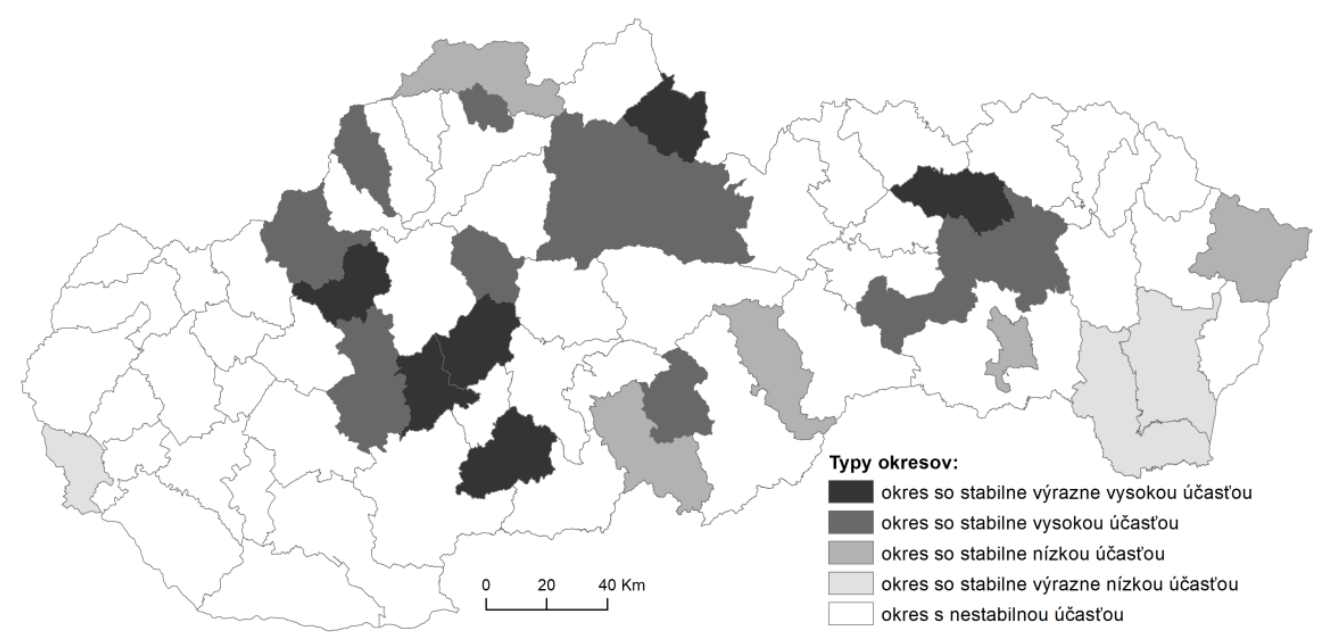

Obr. 3. Okresy so stabilnou volebnou účast'ou vo vol'bách v rokoch 1990 až 1998; Zdroj: Krivý (2016), vlastné výpočty

Ak sa vynechajú vol'by z roku 1990 a pri stabilite volebnej účasti sú použité údaje z parlamentných volieb v rokoch 1992 až 1998, zvýši sa počet okresov so stabilnou volebnou účast’ou na číslo 34 (vid' obr. 4). Zväčšil sa zhluk okresov so stabilne vysokou volebnou účast'ou na strednom Slovensku. Tiež okres Medzilaborce sa vyznačoval stabilne vysokou volebnou účast’ou v tomto období. Na druhej strane sa mestá Košice a okres Malacky vyznačovali stabilne výrazne nízkou volebnou účast'ou. Pribudli tiež nové okresy so stabilne nízkou účast'ou, a to okresy Skalica a Kežmarok.

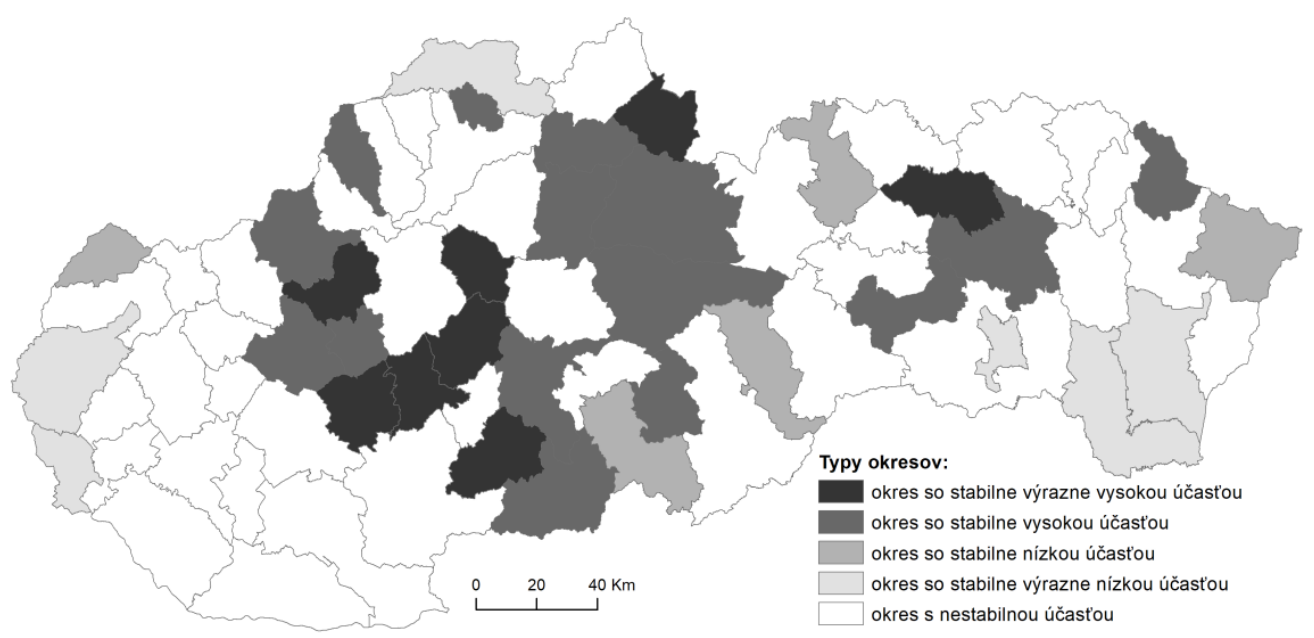

Obr. 4. Okresy so stabilnou volebnou účast'ou vo vol'bách v rokoch 1992 až 1998; Zdroj: Krivý (2016), vlastné výpočty

Po roku 2000 sa na Slovensku konalo pät’ parlamentných volieb a stabilitu volebnej účasti okresov ukazuje obrázok 5. Na prvý pohl'ad je vidno, že stabilnú volebnú účast' malo v období rokov 2002 až 2016 viac okresov ako v 90. rokoch 20. storočia, konkrétne 50. Stabilne vysokú volebnú účast' mali okresy, ktoré boli zhluknuté do štyroch oblastí. Prvou z nich sú mesto 
Bratislava a okres Senec. Druhú oblast' tvoria tri okresy (Nitra, Topol'čany a Zlaté Moravce). Tretí a najväčší zhluk tvoria okresy na strednom Považí, hornej Nitre, Turci, v okolí Žiliny a okresy Banská Bystrica a Zvolen. Poslednú oblast' okresov s vysokou volebnou účastou tvoria okresy Tvrdošín a Liptovský Mikuláš. Naproti tomu stabilne nízku volebnú účast' majú okresy na Záhorí, na juhu Slovenska a s výnimkou okresov Rožňava a Prešov i celé východné Slovensko. Okresy s nestabilnou volebnou účast'ou tvoria pás od okresu Dunajská Streda na sever až k okresu Nové Mesto nad Váhom a d'alej sa pás okresov s nestabilnou účast’ou tiahne až k okresu Krupina. Väčší zhluk okresov s nestabilnou účast’ou je i na severe Slovenska (okresy Čadca, Dolný Kubín, Námestovo a Ružomberok).

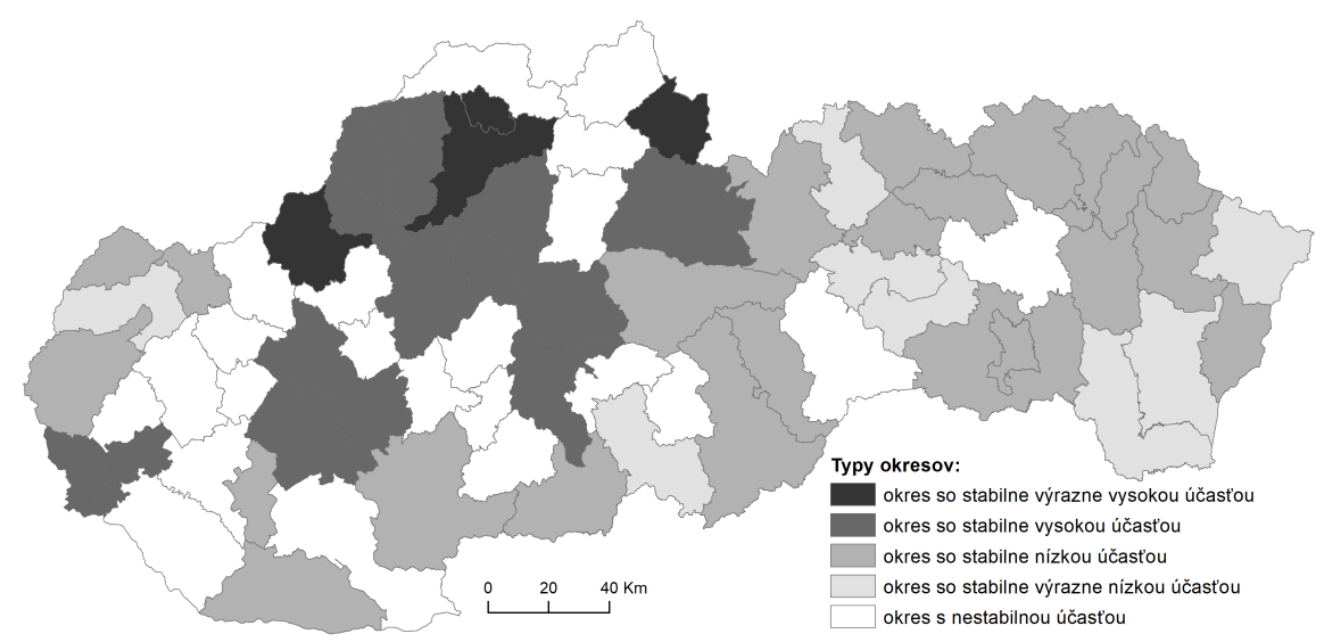

Obr. 5. Okresy so stabilnou volebnou účastou vo vol'bách v rokoch 2002 až 2016; Zdroj: Krivý (2016), vlastné výpočty

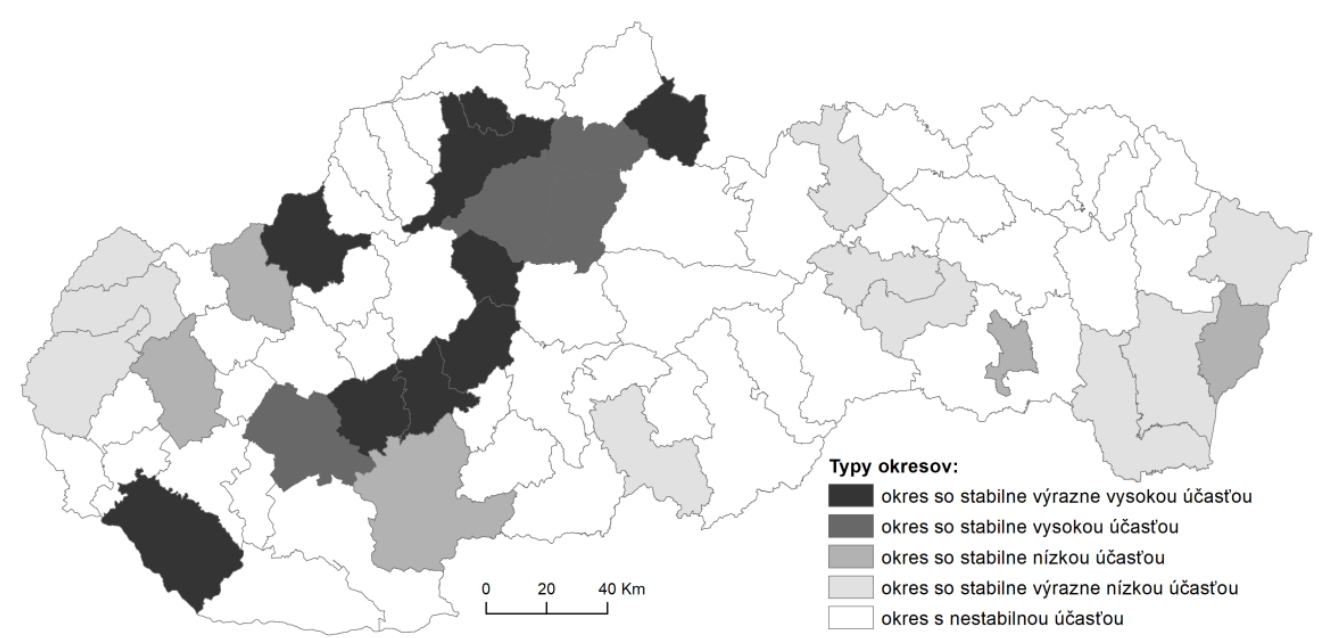

Obr. 6. Okresy so stabilnou volebnou účastou v aspoñ piatich po sebe nasledujúcich vol'bách; Zdroj: Krivý (2016), vlastné výpočty 
Na obrázku 6 vidno, že existuje 28 okresov, ktoré mali aspoň v piatich vol'bách za sebou rovnakú kategóriu volebnej účasti, pričom okresy, ktoré mali vysokú volebnú účast', tvoria pás od okresu Nitra na juhu, až po okres Tvrdošín na severe Slovenska. Okrem týchto okresov mali dlhodobo vysokú volebnú účast' okres Dunajská Streda a okres Trenčín. Naproti tomu okresy, ktoré mali dlhodobo za sebou nízku volebnú účast', sú okresy na Záhorí, Trnava, Nové Mesto nad Váhom, Levice, Lučenec a východoslovenské okresy.

Ďalej sa pozrieme, kol'kokrát v skúmaných vol'bách boli jednotlivé okresy zaradené do kategórií okres s výrazne vysokou volebnou účast’ou a okres s výrazne nízkou volebnou účast'ou. Do kategórie okres s výrazne vysokou volebnou účast'ou sa najčastejšie zaradil okres Tvrdošín, ktorý patril do tejto kategórie vo všetkých deviatich vol'bách (vid' obr. 7). V ôsmich vol'bách do tejto kategórie patril okres Trenčín a v siedmich okresy Kysucké Nové Mesto a Zlaté Moravce. Na druhej strane existuje 19 okresov, ktoré neboli v žiadnych skúmaných vol'bách zaradené do tejto kategórie. Ide o pás okresov od okresu Myjava po okres Levice, okres Čadca, mesto Košice, okresy na ukrajinskej hranici a pás okresov od okresu Lučenec na juhu Slovenska až po okres Stará Lubovňa na severe Slovenska. Tým rozdel'ujú okresy, ktoré boli aspoň raz v kategórii okres s výrazne vysokou volebnou účast'ou, na tri ucelené celky. Jednu oblast' tvoria okresy na Záhorí, Bratislava a jej okolie a okresy na juhu Podunajskej nížiny. Druhá oblast' je tvorená okresmi skoro celého Žilinského a Trenčianskeho kraja, vel'kou čast'ou okresov v Banskobystrickom kraji a severnými okresmi Nitrianskeho kraja. Tretí zhluk tvoria okresy na východnom Slovensku. Týchto dvanást' východoslovenských okresov patrilo do spomínanej kategórie iba vo vol’bách, ktoré sa konali v 90. rokoch 20. storočia. Po roku 2000 nepatril ani jediný východoslovenský okres do kategórie okres s výrazne vysokou volebnou účast'ou, a iba okresy Prešov a Rožňava sa zaradili aspoň v jedných vol'bách po roku 2000 do kategórie okres s vysokou volebnou účast'ou.

Do kategórie okres s výrazne nízkou volebnou účast'ou nepatrilo ani v jedných vol'bách 27 okresov Slovenska, ktoré tvoria ucelený zhluk na strednom a západnom Slovensku (vid' obr. 8). Mimo tento zhluk sú len okresy Trnava, Kysucké Nové Mesto a Prešov. Naproti tomu do tejto kategórie patrili vo všetkých vol'bách okresy Michalovce a Trebišov. Osemkrát patrili do tejto kategórie okresy Lučenec a Snina a sedemkrát okresy Malacky, Senica a mesto Košice.

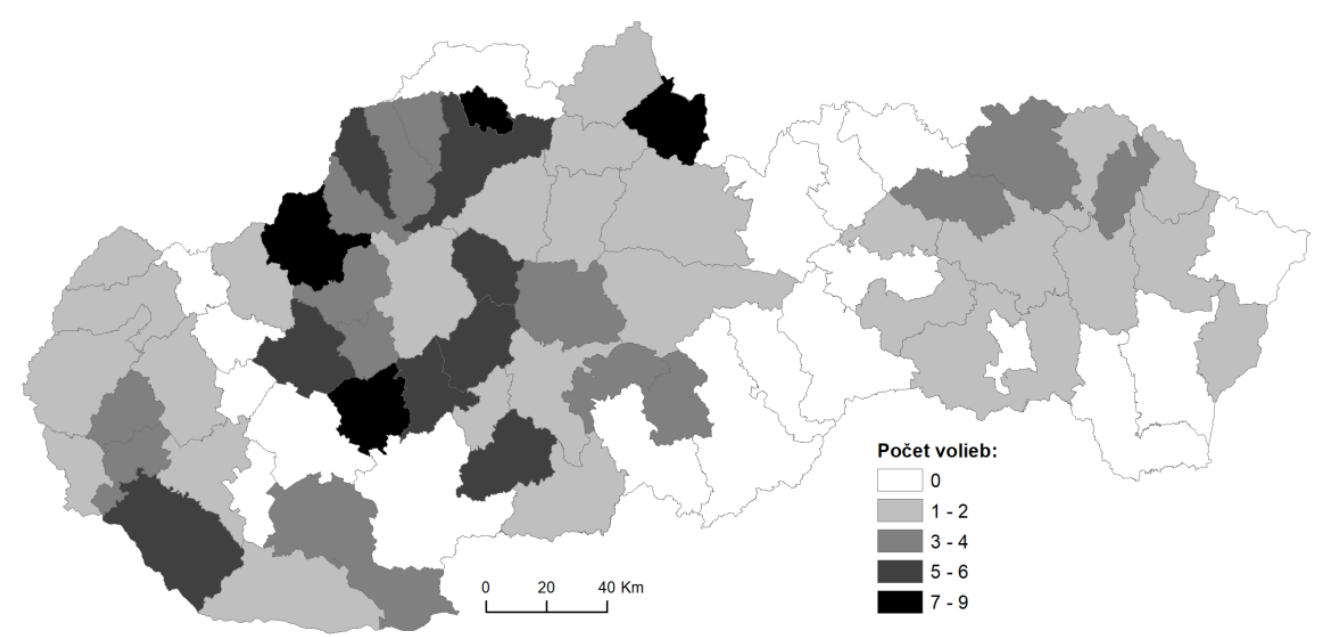

Obr. 7. Počet volieb, v ktorých okres patril do kategórie okres s výrazne vysokou volebnou účastou; Zdroj: Krivý (2016), vlastné výpočty 


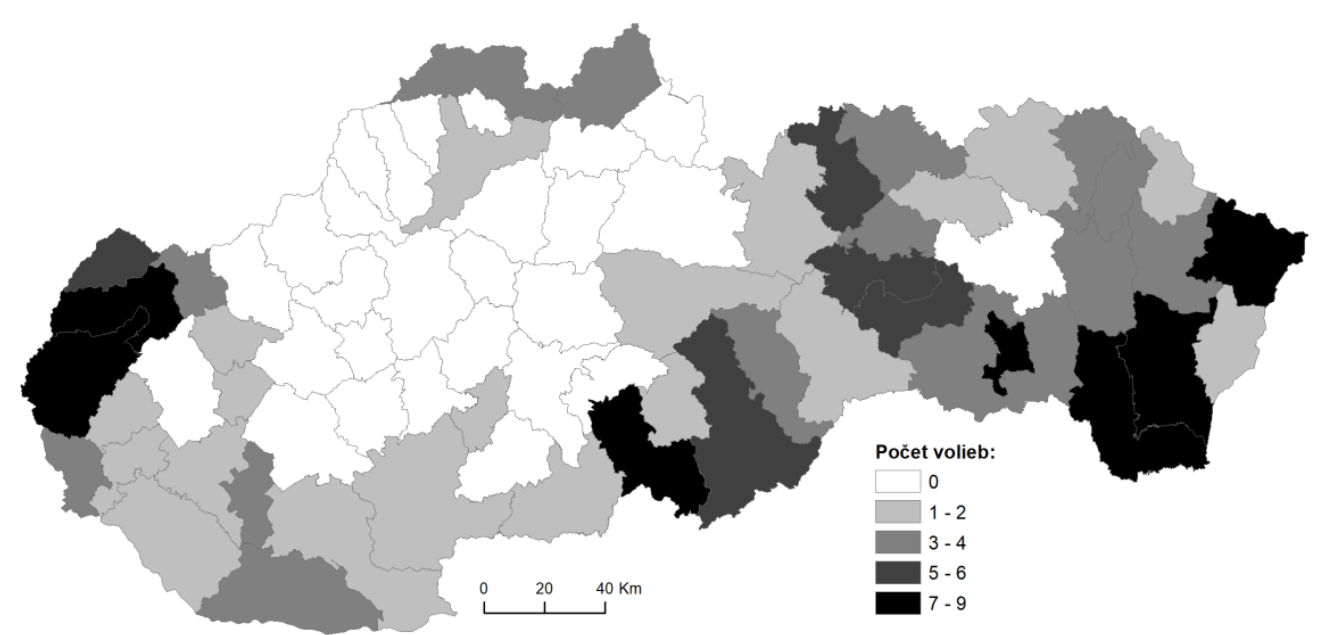

Obr. 8. Počet volieb, v ktorých okres patril do kategórie okres s výrazne nízkou volebnou účastou; Zdroj: Krivý (2016), vlastné výpočty

Na záver sa zameriame na spojitost' medzi priestorovým rozložením volebnej účasti a rozložením dlhodobej nezamestnanosti. Na obrázku 9 vidno určitú podobnost' rozloženia dlhodobej nezamestnanosti, s rozložením okresov so stabilnou volebnou účastou vo vol'bách v rokoch 2002 až 2016 (vid’ obr. 5) a s obrázkom 8. Tiež sme zaznamenali postupný rast negatívneho korelačného koeficientu medzi volebnou účast'ou a dlhodobou nezamestnanost'ou po roku 2000. Ten $\mathrm{v}$ roku 2002 mal hodnotu -0,332, v roku 2010 mal hodnotu $-0,520$ a v posledných vol'bách v roku 2016 bola hodnota korelačného koeficientu $-0,743$. To vedie k domnienke, že nezamestnanost' zohráva dôležitú úlohu v rozložení volebnej účasti a jej význam sa časom zvyšuje.

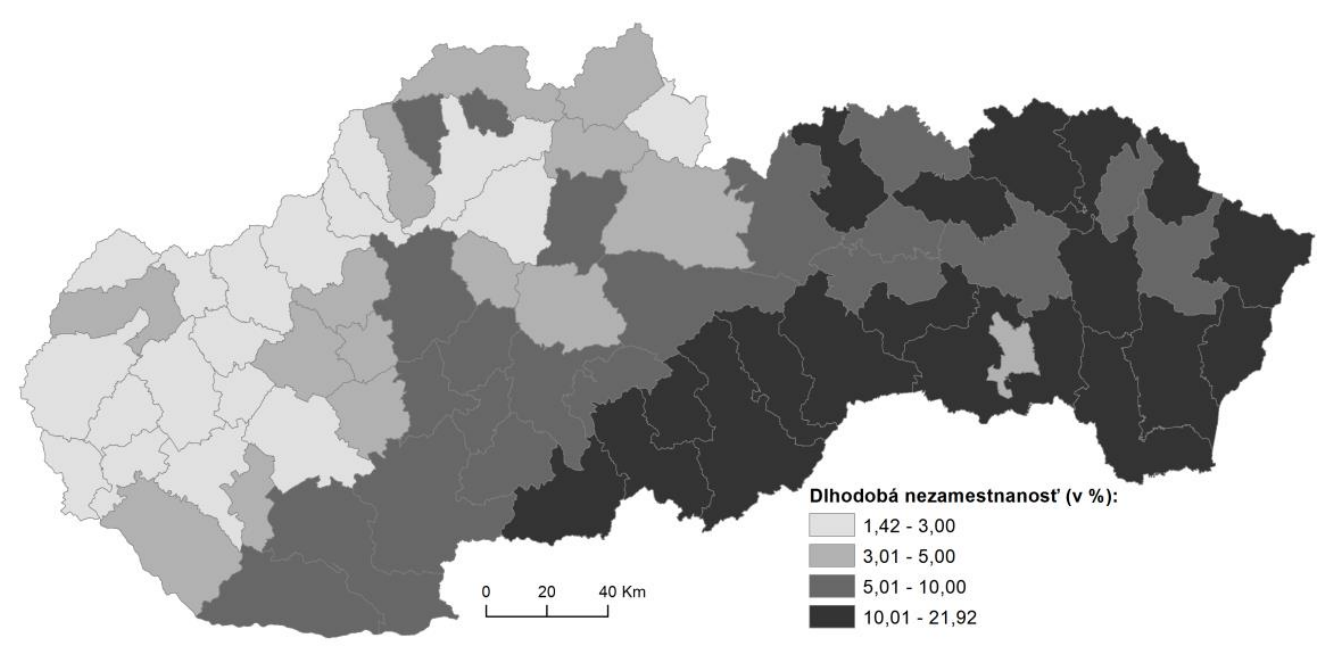

Obr. 9. Rozloženie dlhodobej nezamestnanosti v okresoch k 31. marcu 2016; Zdroj: Ústredie práce, sociálnych vecí a rodiny (2018), vlastné výpočty 


\section{Diskusia}

Stabilita volebnej účasti v 90. rokoch 20 . storočia sa líši od stability volebnej účasti vo vol'bách konaných po roku 2000. Po roku 2000 je ovel'a viac okresov so stabilnou volebnou účast'ou, aj ked' sa ich konalo viac, ako v predchádzajúcom období. To poukazuje na to, že vol'by v 90. rokoch sa vyznačovali väčšou priestorovou premenlivost'ou ako vol'by v 21 . storočí, na čo poukázali niektorí autori (Madleňák 2012, Gyárfášová, Krivý 2013). Po roku 2000 sa nachádzali okresy so stabilne vysokou volebnou účast'ou na severnom Slovensku, takisto ako v devät'desiatych rokoch, avšak počet okresov v tejto oblasti sa zvýšil. Naproti tomu vymizli okresy so stabilne vysokou volebnou účast'ou na východnom Slovensku a okresy Bánovce nad Bebravou, Krupina, Žarnovica a Žiar nad Hronom, ktoré mali v devät'desiatych rokoch stabilne výrazne vysokú volebnú účast', mali po roku 2000 nestabilnú volebnú účast' (porovnaj obrázky 4 a 5). Tieto okresy patrili k baštám hnutia HZDS, čo mohlo zvyšovat' ich hodnotu volebnej účasti (Szőllös 2000). Výrazne sa zmenilo i postavenie Bratislavy. Do roku 2000 sa Bratislava vyznačovala stabilne výrazne nízkou volebnou účast’ou, ale po roku 2000 má stabilne vysokú volebnú účast'. Po roku 2000 sa tiež zvýšil počet okresov na východnom a južnom Slovensku so stabilne nízkou volebnou účast'ou, čo môže súvisiet's javom poklesu záujmu mad'arského obyvatel'stva o vol'by, ktorý zaznamenal Krivý (2012).

Z analýzy jasne vyplýva, že vývoj volebnej účasti na Slovensku sa nedá vysvetlit' len podl'a teórie habituálneho hlasovania, pretože len 13 regiónov na Slovensku malo počas skúmaného obdobia stabilnú volebnú účast' (vid’ obr. 1). Takže existujú aj iné príčiny rozloženia volebnej účasti na Slovensku.

Zaujímavé výsledky ponúka štúdia aj vzhl’adom k teóriám modernizácie a rozčarovania. $\mathrm{V}$ devät'desiatych rokoch sa regióny Bratislavy a Košíc vyznačovali vel'mi nízkou volebnou účast'ou. To zodpovedá zisteniam z predošlých štúdií (Kostelecký 2001, Kostadinova 2003) a podporuje to teóriu rozčarovania. Avšak od volieb v roku 2002 volebná účast' v meste Košice zostáva nízka, ale volebná účast’ v Bratislave naopak, patrí k najvyšším. Tým viacej pre Bratislavu po roku 2000 platí teória modernizácie. Túto zmenu vo volebnej účasti v najväčšom meste Nový (2013) vysvetl'uje tým, že sa zvyšuje počet voličov, ktorí už vyrastali $\mathrm{v}$ demokratickej spoločnosti. Tým ich prístup k vol'bám viac zodpovedá prístupu voličov v západných krajinách s dlhotrvajúcimi demokraciami, a tým začína byt' teória modernizácie významnejšia pre Slovensko. Ale podl'a teórie modernizácie, by mala narastat' volebná účast' aj v meste Košice, k čomu však nedochádza. To nabáda k tomu, že musia existovat' ešte d'alšie faktory volebnej účasti. Napríklad Kostelecký (2001) podotýka, že rozloženie volebnej účasti závisí na socioekonomických faktoroch, ako je nezamestnanost', národnost', náboženstvo alebo sociálny status obyvatel'stva. A ak sa tieto socioekonomické faktory nemenia, nemala by sa menit' ani výška volebnej účasti. Potvrdilo sa, že v okresoch, v ktorých je vysoká dlhodobá nezamestnanost', bola i nízka volebná účast'. Tiež sa ukázalo, že sa postupom času zvyšuje korelačný koeficient vzt'ahu medzi nezamestnanost'ou a volebnou účast'ou, čo zvyšuje platnost' teórie socioekonomického statusu a zdrojov v prostredí slovenských volieb.

Ďalšie socioekonomické faktory, ktoré by viac potvrdili platnost' teórie socioekonomického statusu a zdrojov, sme pre limitovaný obsah práce neoverovali a bolo by dobré to dôkladnejšie analyzovat' $v$ d'alších štúdiách. Okrem toho stabilitu volebnej účasti môžu ovplyvňovat' kontextuálne faktory, mobilizačný potenciál niektorých politických strán, celková politická situácia a charakter politickej sút’aže v jednotlivých vol'bách. Tieto faktory môžu v rôznej miere mobilizovat' voličov politických strán, alebo voličov všeobecne. 


\section{Záver}

Stabilita volebnej účasti v parlamentných vol’bách na Slovensku sa menila. Okresy sa vo vol'bách konaných v 90. rokoch vyznačovali väčšou zmenou volebnej účasti v rámci ich postavenia medzi ostatnými okresmi. K okresom so stabilne nízkou volebnou účast’ou patrili mestá Bratislava a Košice, okresy na Zemplíne, juhu stredného Slovenska a v prípade vynechania volieb v roku 1990, k nim patrili aj okresy na Záhorí. Okresy so stabilne vysokou účast’ou sa nachádzali hlavne v Trenčianskom, Žilinskom a Banskobystrickom kraji (vid' obr. 3 a 4).

Naproti tomu sa volebná účast' v okresoch vo vol'bách, ktoré sa konali po roku 2000 vyznačovala vysokou stabilitou (vid' obr. 5). Len 22 okresov bolo takých, u ktorých sa volebná účast' v tomto období menila výrazne. Okresy zo stabilne nízkou volebnou účast'ou sa nachádzajú takmer na celom východnom Slovensku, na juhu krajiny a na Záhorí. Stabilne vysokú volebnú účast' majú okresy na severe stredného Slovenska, v Trenčianskom kraji, v okolí Nitry a Bratislavy. Tiež je vidno, že došlo $\mathrm{k}$ zmene volebnej účasti v Bratislave a v okresoch v okolí Prešova.

Za celé skúmané obdobie malo stabilnú účast' celkovo 13 okresov na Slovensku (vid' obr. 1). Z toho sedem okresov, ktoré sa až na výnimku okresu Zlaté Moravce, nachádzajú v Žilinskom alebo Trenčianskom kraji, malo stabilne vysokú volebnú účast'. Okres Tvrdošín je jediným okresom, ktorý vo všetkých vol'bách patrí do štvrtiny okresov s najvyššou volebnou účast'ou. $\mathrm{K}$ okresom so stabilne nízkou volebnou účast'ou patria okresy na Zemplíne, mesto Košice a dva okresy na juhu stredného Slovenska - Lučenec a Revúca.

V rokoch 1990 až 2016 nepatrili nikdy do štvrtiny okresov s najvyššou volebnou účast’ou mesto Košice, okres Čadca, okresy na severe východného Slovenska a niektoré okresy na juhu Slovenska (vid' obr. 7). Zaujímavá je línia okresov tiahnuca sa od okresu Myjava po okres Levice, kde volebná účast' nikdy nebola výrazne vysoká a oddel'uje tak dva väčšie celky, kde bola aspoň raz zaznamenaná vysoká volebná účast'. Všetky východoslovenské okresy, ktoré boli aspoň raz v štvrtine okresov s najvyššou volebnou účast'ou, dosiahli túto kategóriu vo vol'bách, ktoré sa konali pred rokom 2000. Naproti tomu okresy, ktoré nikdy nepatrili do štvrtiny okresov s najnižšou volebnou účast'ou, až na malé výnimky, tvoria celok na strednom a západnom Slovensku (vid' obr. 8). To vedie k domnienke, že na Slovensku je silná priestorová diferenciácia volebnej účasti, ktorá sa navyše vo vol'bách v 21. storočí posilňuje tým, že sa zvyšuje počet okresov, ktoré si udržujú stabilnú volebnú účast', v porovnaní s ostatnými okresmi.

Tiež sa ukázalo, že v okresoch, kde je dlhodobo vysoká nezamestnanost', tak je i nízka volebná účast' (porovnaj obrázky 5,8 a 9), pričom sa spojitost' medzi výškou nezamestnanosti a volebnou účast'ou $\mathrm{v}$ čase zvýrazňuje. Vd'aka tomu je možné predpokladat' aspoň čiastočnú platnost' teórie socioekonomického statusu a zdrojov v rámci parlamentných volieb na Slovensku.

Táto štúdia je deskriptívne zameraná, avšak ponúka prehl'adnú analýzu a vývoj priestorového rozloženia volebnej účasti doterajších parlamentných volieb a niekol'ko námetov, na ktoré by sa mohli budúce štúdie zamerat'. Konkrétne by sa mohli pokúsit' pomocou socioekonomických, kultúrnych a národnostných charakteristík vysvetlit' dôvody, prečo si dané okresy udržujú stabilne vysokú účast', stabilne nízku účast' alebo majú premenlivú volebnú účast'. Tiež by mohlo byt' zaujímavé venovat' sa tejto problematike na úrovni obcí.

\section{Literatúra}

BARÁTH, J., SZÖLLÖS, J., ČERNÁK, P. 1995: Analýza stability územia volebnej podpory vybraných politických strán (na základe výsledkov volieb 1990, 1992 a 1994). Geografický časopis, 47, 247-259.

CAMPBELL, A., CONVERSE, P., MILLER, W., STOKES, D. 1960: The American voter. New York (John Wiley \& Sons). 
FRANKLIN, M. N. 2004: Voter Turnout and the Dynamics of Electoral Competition in Established Democracies since 1945. Cambridge (Cambridge University Press).

GREEN, D. P., SHACHAR, P. 2000: Habit Formation and Political Behaviour: Evidence of Consuetude in Voter Turnout. British Journal of Political Science, 30(4), 561-573. DOI: https://doi.org/10.1017/S0007123400000247.

GYÁRFÁŠOVÁ, O., KRIVÝ, V. 2013: Vzorce voličského správania. Krivý, V. ed. Ako sa mení slovenská spoločnost'. Bratislava (Sociologický ústav SAV), 257-342.

JEHLIČKA, P., SÝKORA, L. 1991: Stabilita regionální podpory tradičních politických stran v českých zemích. Sborník České geografické společnosti, 96(2), 81-95.

KOSTADINOVA, T. 2003: Voter turnout dynamics in post-communist Europe. European Journal of Political Research, 42(6), 741-759. DOI: https://doi.org/10.1111/1475-6765. 00102.

KOSTELECKÝ, T. 2001: Vzestup nebo pád politického regionalismu? Změny na politické mapě v letech 1992 až 1998 - srovnání České a Slovenské republiky. Praha (Sociologický ústav Akademie věd České republiky).

KOSTELECKÝ, T., KRIVÝ, V. 2015: Urbánno-rurálne rozdiely voličského správania v Česku a na Slovensku. Sociológia, 47(4), 390-413.

KRIVÝ, V. 1999: Čo prezrádzajú volebné výsledky? Parlamentné vol'by 1992-1998. Bratislava (Inštitút pre verejné otázky).

KRIVÝ, V. 2012: Výsledky volieb '12: čo sa zmenilo, čo zostáva. Krivý, V. ed. Slovenské vol'by '12: čo im predchádzalo, postoje a výsledky. Bratislava (Sociologický ústav SAV), 47-136.

KRIVÝ, V. 2016: Výsledky volieb 1929 - 2016 za obce na Slovensku. Retrieved from: http://sasd.sav.sk/sk/data_katalog_abs.php?id=sasd_2010001.

MADLEŇÁK, T. 2012: Regionálna diferenciácia volebného správania na Slovensku (19982010). Bratislava (VEDA).

MADLEŇÁK, T., PINK, M. 2012: Základné priestorové vymedzenie voličskej základne politických strán na Slovensku 1994-2010. Pink, M. ed. Volební mapy České a Slovenské republiky po roce 1993: vzorce, trendy, promény. Brno (Centrum pro studium demokracie a kultury), 47-88.

MIKUŠ, R. 2014: Politická diferenciácia územia Slovenska z pohl’adu volebných preferencií. Lauko, V. ed. Regionálne dimenzie Slovenska. Bratislava (Univerzita Komenského), 67-125.

MIKUŠ, R., GURŇÁK, D. 2014: Špecifiká volebnej účasti v obciach Košického kraja vo volbách na rôznych úrovniach v rokoch 1999 - 2014. Geographia Cassioviensis, 8(2), 150-161.

MO, J., BRADY, D., RO, J. 1991: Urbanization and Voter Turnout in Korea: An Update. Political Behavior, 13(1), 21-32. DOI: https://doi.org/10.1007/BF00996997.

NORRIS, P. 2002: Democratic phoenix: reinventing political activism. Cambridge (Cambridge University Press).

NOVÝ, M. 2013: Volební účast a její determinanty ve starých a nových demokraciích Evropy. Sociológia, 45(2), 195-228.

PACEK, A. C., POP-ELECHES, G., TUCKER, J. A. 2009: Disenchanted or Discerning: Voter Turnout in Post-Communist Countries. Journal of Politics, 71(2), 473-491. DOI: https://doi.org/10.1017/s0022381609090409.

PLEŠIVČÁK, M. 2011: Postavenie regiónov Slovenska z hl'adiska území volebnej podpory politických strán v parlamentných vol’bách v rokoch 2002-2010. Geografický časopis, 63(3), 227-251. 
PLEŠIVČÁK, M., BUČEK, J., BAČÍK, V., KUSENDOVÁ, D. 2016: Theoretical and methodological notes on current options related to examination of voting behaviour - The geographical approach. Acta Geographica Universitatis Comenianae, 60(2), 151-170.

ROSENSTONE, S. J., HANSEN, J. M. 2009: Mobilization, participation, and democracy in America. New York (Longman).

SZABÓ, B., TÁTRAI, P. 2016: Regional and social cleavages in the Slovak elections after the change of the regime. Geografický časopis, 68(3), 195-212.

SZÖLLÖS, J. 2000: Stabilita volebnej podpory vybraných politických strán a ich zoskupení na Slovensku v rokoch 1990-1998. Geografický časopis, 52(3), 243-267.

ÚSTREDIE PRÁCE, SOCIÁLNYCH VECÍ A RODINY 2018: Nezamestnanost' - mesačné štatistiky. Retrieved from: http://www.upsvar.sk/statistiky/nezamestnanost-mesacne-statistiky.html?page_id=1254.

WOLFINGER, R. E., ROSENSTONE, S. J. 1980: Who Votes? New Haven (Yale University Press).

Pod'akovanie: Tento článok vznikol v rámci projektu špecifického výskumu MUNI/A/1356/2019 Výzkum proměn geografických procesů a vatahů v prostoru a čase.

\section{Adresa autora}

Mgr. Dominik Kevický

Geografický ústav

Př́rodovědecká fakulta

Masarykova univerzita

Kotlářská 267/2, 61137 Brno

Česko

423695@mail.muni.cz 